\title{
COMMUNITY BASED INTERVENTION FOR REDUCING UNDERNUTRITION IN INFANTS AND YOUNG CHILDREN IN KARAD, MAHARASHTRA
}

\author{
Suryakant Ingale1, Jaiom Dagar²
}

${ }^{1}$ Associate Professor, Department of Paediatrics, Krishna Institute of Medical Sciences.

${ }^{2}$ Resident, Department of Paediatrics, Krishna Institute of Medical Sciences.

\begin{tabular}{l}
\hline ABSTRACT \\
\hline BACKGROUND \\
Prevalence of undernutrition among young children is very high in rural India; it is one of the major problems faced by the developing \\
countries. Undernutrition continues to be a major public health problem despite years of social schemes by various governments \\
and other preventive measures.
\end{tabular}

Aim of this study are,

1. To evaluate undernutrition status in community (Anganwadi) near Karad.

2. To evaluate effectiveness of Krishna Laddu.

\section{MATERIALS AND METHODS}

Study Design- This was a community based interventional study.

Study Period- 06 months (Feb, 2014 to July, 2015).

Sample Size- All under-nourished children in the selected community (Anganwadi).

\section{RESULTS}

A total of 120 children of age group between 6 months and 5 years were surveyed from 2 Anganwadis and data was analysed. Undernutrition was observed to be more common among females than male, but this difference was not found to be statistically significant ( $\mathrm{p}>0.05)$. Grade I PEM (IAP classification) was observed to be more common; however, SAM was noted in $13.7 \%$ of undernourished children. Out of 58 under-nourished children, 50 children were among 12 to 60 months age group who were given 2 Krishna Laddus/day for 3 months and analysed after 3 months (Post-intervention). Total 84\% children showed more than average improvement in weight gain ( $>500 \mathrm{~g} / 3$ months) after Krishna Laddu supplementation.

\section{CONCLUSION}

Our study reinforces the importance of correct infant and child feeding practices, family planning practices, appropriate maternal care and female literacy in prevention of undernutrition among under-five children.

\section{KEYWORDS}

Under-Weight; Wasting; Stunting; Dietary Habits; Krishna Laddu.

HOW TO CITE THIS ARTICLE: Ingale S, Dagar J. Community based intervention for reducing undernutrition in infants and young children in Karad, Maharashtra. J. Evolution Med. Dent. Sci. 2016;5(94):6949-6952, DOI: 10.14260/jemds/2016/1572

\section{BACKGROUND}

Protein Energy Malnutrition (PEM) is a widely prevalent form of malnutrition among children under 5 years and is still the major problem in our country especially in urban slums. Malnutrition is defined as any deviation from normal nutrition. Children under 5 years represent the vulnerable and vital target group where malnutrition plays a pivotal role in their mortality and morbidity along with delayed mental and motor development during important period of brain growth. The various risk factors identified for undernutrition are related to the child, mother and largely their environment.

\section{Financial or Other, Competing Interest:}

Community based Intervention for reducing under nutrition in Infants and young Children in Karad, Maharashtra. A Patent has been filed for Krishna Laddu,

Submission 11-10-2016, Peer Review 04-11-2016,

Acceptance 10-11-2016, Published 24-11-2016.

Corresponding Author:

Dr. Jaiom Dagar,

IHR Hostel, KIMSDU, Karad,

Satara, Maharashtra-415110.

E-mail: jai.dagar05@gmail.com

DOI: $10.14260 /$ jemds/2016/1572
Adequate nutrition during infancy and childhood is fundamental to a child's maximum developmental potential[1] while poor quality of infant and young child feeding practices play the most important role in the aetiology of undernutrition among the children under 5 years.[2] In view of the high prevalence of undernutrition in rural India, the objective of present research was to estimate the prevalence of undernutrition among age group (6 months to 5 years) through anthropometric measurements and to evaluate effectiveness of Krishna Laddu. Many factors like high prevalence of infection and worm infestation, undernutrition among the children under 5 years in India, results mostly because of inappropriate infant and young child feeding practices. Also, India has implemented the largest child development programme (ICDS) in the world, yet improvement in prevalence of undernutrition is limited.[3] The prevalence of underweight among children in India is amongst the highest in the world, and nearly doubles that of SubSaharan Africa where approximately 60 million children are underweight.[3] Beliefs like not feeding colostrums to newborn as it is considered witch's milk and cultural practices of prelacteal feeds like giving honey, expose the child to 
infections which contributes to under nutrition. [4] Krishna Laddu prescribed for under-nourished children is such that the family can provide it within their limited income. It can be easily prepared at home, doesn't perish easily, culturally acceptable and locally available. It provides $487.5 \mathrm{Kcal}$ and $13.1 \mathrm{~g}$ protein per $100 \mathrm{~g}$.

\section{Aims and objectives}

1. To evaluate undernutrition status in community (Anganwadi) near Karad.

2. To evaluate effectiveness of Krishna Laddu.

\section{MATERIALS AND METHODS}

\section{Setting}

Anganwadi at Kole Khind and Sanjay Nagar in Karad Taluka.

\section{Study Design}

This was a community based interventional study.

\section{Study Period}

06 months (Feb, 2015 to July, 2015).

\section{Sample Size}

All under-nourished children in the selected community (Anganwadi)

\section{Inclusion Criteria}

All under-nourished children in selected community according to IAP classification, age group 6 months to 5 years.

\section{Exclusion Criteria}

1. Children with normal and over-nutrition.

2. Children with any malformations or deformity were excluded.

3. Children whose parents or guardians did not consent for the study.

4. Children who were attending the anganwadi temporarily and children who were severely ill were also excluded.

\section{Methodology}

This was a community based interventional study and was conducted in anganwadi at Kole Khind and Sanjay Nagar in Karad Taluka, Satara district (Maharashtra). The trial was approved by ethical committee of Krishna Institute of Medical Sciences before conduction. Written informed consent was obtained from the parents of children prior to the enrolment of subjects in the study. The intervention used was 2 Krishna Laddus (Marathi Word meaning a spherical eatable) per day for 3 months for children above 1 year of age. Krishna Laddus were prepared using various food items available locally. The ingredients of Laddu are given in Fig. 1. The subjects were evaluated after 3 months and anthropometry was recorded and it was compared with average weight gain in this age group (2 kg/ year).

\section{Outcome Measures and Follow-Up}

Outcome was measured in terms of various anthropometry parameters and improvement in knowledge of parents of children involved in our study.

\section{Statistical Analysis}

The data related to undernutrition was collected such as age, gender and grade of PEM. The categorical data is presented as frequencies and percentages.

\begin{tabular}{|c|c|c|c|c|c|c|}
\hline Ingredient & Wt. & $\begin{array}{c}\text { Calories } \\
\text { (Kcal) }\end{array}$ & $\begin{array}{c}\text { Protein } \\
\text { (g) }\end{array}$ & \begin{tabular}{|c|} 
Carbohydrate \\
(g)
\end{tabular} & \begin{tabular}{|l|} 
Fat \\
(g) \\
\end{tabular} & \begin{tabular}{|c}
$\begin{array}{c}\text { Calcium } \\
(\mathrm{mg})\end{array}$ \\
\end{tabular} \\
\hline \multirow{3}{*}{ Soybean } & 15 & 64.8 & 6.4 & 2.94 & 2.92 & 36 \\
\hline & $\begin{array}{l}\text { Per } \\
100\end{array}$ & 432 & 43.2 & 19.6 & 19.5 & 240 \\
\hline & $\mathrm{g}$ & & & & & \\
\hline \multirow[b]{2}{*}{ Ragi } & 05 & 16.4 & 0.36 & 3.6 & 0.06 & 17.2 \\
\hline & \begin{tabular}{|c|} 
Per \\
100 \\
$\mathrm{~g}$
\end{tabular} & 328 & 7.3 & 72 & 1.3 & 344 \\
\hline \multirow[b]{2}{*}{ Chana Dal } & 05 & 18 & 0.85 & 0.26 & 0.26 & 10.1 \\
\hline & $\begin{array}{c}\text { Per } \\
100 \\
\mathrm{~g}\end{array}$ & 360 & 17.1 & 5.2 & 5.3 & 202 \\
\hline \multirow[b]{2}{*}{ Groundnut } & 05 & 28.35 & 0.27 & 3.71 & 4.42 & 4.5 \\
\hline & $\begin{array}{l}\text { Per } \\
100\end{array}$ & 567 & 5.4 & 74.2 & 88.4 & 90 \\
\hline \multirow[b]{2}{*}{ Jaggery } & 20 & 76.6 & 0.02 & 19.6 & - & 16 \\
\hline & \begin{tabular}{|c|} 
Per \\
100 \\
g
\end{tabular} & 383 & 0.1 & 98.1 & - & 80 \\
\hline \multirow[b]{2}{*}{$\begin{array}{c}\text { Groundnut } \\
\text { Oil }\end{array}$} & 10 & 88.4 & - & - & 9.5 & - \\
\hline & $\begin{array}{l}\text { Per } \\
100\end{array}$ & 884 & - & - & 95 & - \\
\hline \multirow[b]{2}{*}{ Total } & 60 & 292.5 & 7.9 & 30.1 & 17.1 & 83.8 \\
\hline & $\begin{array}{c}\text { Per } \\
100 \\
\mathrm{~g}\end{array}$ & 487.5 & 13.1 & 50.1 & 28.6 & 139.6 \\
\hline \multicolumn{7}{|c|}{ Figure 1. Ingredients of Krishna Laddu } \\
\hline
\end{tabular}

Cardamom- $10 \mathrm{~g} / 3.5 \mathrm{~kg}$ (For Flavour)

\section{RESULTS}

A total of 120 children of age group between 6 months and 5 years were surveyed from 2 anganwadis and data was analysed. Finally, the prevalence of undernutrition among the study population came around $58(48.3 \%)$.

Among the children, 47 (82.4\%) were delivered through normal vaginal delivery, $32(55.2 \%)$ had a normal birth weight and $30(51.8 \%)$ were second order children. Undernutrition was observed to be more common among females than males (Table 1), but this difference was not found to be statistically significant $(\mathrm{p}>0.05)$.

\begin{tabular}{|c|c|c|}
\hline & $\mathbf{N = 5 8}$ & \\
\hline Male & 26 & $44.8 \%$ \\
\hline Female & 32 & $55.2 \%$ \\
\hline \multicolumn{2}{|c|}{ Table 1. Shows the Distribution of Under } \\
nourished Children According to their Gender \\
\hline
\end{tabular}

Majority of them were in the age group of 13-24 months 17 (29.3\%), belonging to joint family $41(70.7 \%)$ and upper lower socioeconomic class $22(38 \%)$.

\begin{tabular}{|c|c|c|}
\hline & Number (n=58) & Percentage \\
\hline 6-12 Months & 08 & 13.7 \\
\hline 13-24 Months & 17 & 29.3 \\
\hline 25-36 Months & 13 & 22.4 \\
\hline 37-48 Months & 09 & 15.5 \\
\hline 49-60 Months & 11 & 18.9 \\
\hline \multicolumn{3}{|c|}{ Table 2. Shows the Distribution of Under } \\
nourished Children According to their age Group \\
\hline
\end{tabular}


Grade I PEM (IAP classification) was observed to be more common; however, SAM was noted in $13.7 \%$ of undernourished children.

\begin{tabular}{|c|c|c|}
\hline Weight for Age & Number (N=58) & Percentage \\
\hline Grade I & 23 & 39.6 \\
\hline Grade II & 18 & 31.0 \\
\hline Grade III & 09 & 15.5 \\
\hline Grade IV & 08 & 13.7 \\
\hline \multicolumn{2}{|c|}{ Table 3. Shows the Distribution of Under } \\
nourished Children According to IAP Classification \\
\hline
\end{tabular}

Out of 58 under-nourished children, 50 children were among 12 to 60 months age group who were analysed after 3 months (Post-intervention). Average weight gain in 3 months in this age group was taken to be $500 \mathrm{~g}$ as per various standards. Total $84 \%$ children showed more than average improvement in weight gain ( $>500 \mathrm{~g} / 3$ months) after Krishna Laddu supplementation.

\begin{tabular}{|c|c|c|}
\hline $\begin{array}{c}\text { Weight Gain } \\
\text { in 3 Months }\end{array}$ & $\begin{array}{c}\text { Number } \\
\mathbf{( N = 5 0 )}\end{array}$ & Percentage \\
\hline$>700 \mathrm{~g}$ & 17 & 34 \\
\hline$>600 \mathrm{~g}$ & 22 & 44 \\
\hline$>500 \mathrm{~g}$ & 03 & 06 \\
\hline$<500 \mathrm{~g}$ & 08 & 16 \\
\hline \multicolumn{2}{|c|}{ Table 4. Shows Weight Improvement in } \\
Undernutrition Children after Intervention \\
\hline
\end{tabular}

Regarding mothers of the children, majority were in the age grouping 21-25 years 37 (63.8\%). About 33 (56.8\%) of the mothers were educated till middle class school. Most common profession of father of under-nourished children was farming followed by animal husbandry.

\section{DISCUSSION}

Undernutrition is an important cause of childhood mortality and morbidity; it may lead to permanent impairment of physical and mental growth in those who survive.[5] Our study has shown higher rates of undernutrition among girl child, similar findings were noticed in a study conducted in West Bengal where undernutrition among girls (54.8\%) exceeded those of boys $(46.8 \%)$ and the difference was higher for moderate and severe forms. ${ }^{[6]}$ It is supported by other authors as well.[7,8] Our study has shown 55.2 and $44.8 \%$ undernutrition among boys and girls respectively, where as a study by Hasan et al[9] has shown higher incidence of undernutrition among boys as compared to girls.

Although National Family Health Survey-4 (NFHS-4) reported improvement in nutritional status of children over all,[10] the proportion of undernutrition in higher birth order $(>3)$ was found to be higher ,so they are at higher risk of undernutrition than those with first birth order; [11] which was also observed in our study. In our study, majority of undernourished children were in the age group of 13-24 months - 17 (29.3\%), belonging to joint family 41 (70.7\%) and upper lower socioeconomic class 22 (38\%). In another study by B. Bhandari et al,[12] 137 SAM children were studied, they found maximum number of children in study were between 13 to 36 months of age $(70.06 \%)$ of which 85 (62\%) were male and 52 (37.9\%) were females which is in accordance with our study. In our study, total $84 \%$ children of above 1 year of age showed more than the average improvement in weight gain $(>500 \mathrm{~g} / 3$ months) after daily 2 Krishna Laddu supplementation for 3 months. Our community based intervention (2 Krishna Laddu supplementation/day) made the biggest impact in SAM patients. The number of the "severely wasted" was reduced in the community. There is a recommendation by various authors for food supplementation in food insecure areas to improve undernutrition.[13] In order to increase calorie intake, children should be given two healthy snacks besides the three regular meals of the day. Low income families can improve their nutritional health within the resources available to them. In recent times, one of the studies for reducing child malnutrition was done in Thailand. ${ }^{[14]}$ Nutritional intervention with Krishna Laddu showed significant weight gain among children with grade I and grade II protein energy malnutrition.

Our goal is to restore to near normal of the nutritional status of the undernourished child and to have a sustained improved physical \& mental growth, performance of the child, siblings \& other children in the household.

\section{CONCLUSIONS}

India today stands at a very vulnerable place with one of the highest prevalence of undernutrition in the world despite improvement in food availability and poverty scenario. Our study reinforces the importance of correct infant and child feeding practices, family planning practices, appropriate maternal care, and female literacy in prevention of undernutrition among children under 5 years. The reduction in mortality in children under 5 years is possible by expanding effective preventive and curative interventions that target the main causes of undernutrition. This study did confirm the impact of nutritional interventions on the nutritional status of the school children. The high incidence of undernutrition may be attributed to improper dietary habits, unawareness of balanced diet and high frequency of early age group paediatric infestations, poor prenatal nutrition, food insecurity and low family income.

\section{REFERENCES}

1. Dewey K. Guiding principles for complementary feeding of the breastfed child. Geneva: World Health Org, 2003.

2. World Health Organization. Complementary feeding: report of the global consultation, and summary of guiding principles for complementary feeding of the breastfed child. Geneva, Switzerland: World Health Organization, 2001.

3. Gragnolati M, Shekar M, Gupta DM, et al. India's undernourished children: a call for reform and action. Washington, DC: Health, Nutrition, and Population Division, World Bank, 2005.

4. Deshpande JD, Giri PA, Phalke DB, et al. Socio-cultural practices in relation to breast feeding, weaning and child rearing among Indian mothers and assessment of nutritional status of children under five in rural India. Australas Med J 2010;3(9):618-24.

5. Park K. Park's textbook of preventive and social medicine. 23 ${ }^{\text {rd }}$ edn. Jabalpur: M/s Banarsidas Bhanot Publishers 2015.

6. Banerjee B, Mandal ON. An intervention study in malnutrition among infants in a tribal community of West Bengal. Indian J Community Med 2005;30(1):27-9. 
7. Mittal A, Singh J, Ahluwalia SK. Effect of maternal factors on nutritional status of 1-5-year-old children in urban slum population. Indian J Community Med 2007;32(4): 264-7.

8. Kumar SA, Kumar SD, Ashok NC, et al. Protein energy malnutrition and its association with immunization status and common morbidities among 1-5 year aged children in southern part of India, Mysore. Int J Cur Res Rev 2013;5(2):105-10.

9. Hasan I, Zulkifle M, Ansari AH. An assessment of nutritional status of the children of government Urdu higher primary schools of Azad Nagar and its surrounding areas of Bangalore. Archive of Applied Science and Research 2011;3(3):167-76.

10. National Family Health Survey-4 (NFHS-4) Report (20152016) Ministry of Health and Family Welfare India.
11. Harishankar, Dwivedi S, Dabral SB, et al. Nutritional status of children under 6 years of age. Indian J Prev Soc Med 2004;35(3):156-62.

12. Bhandari $B$, Chib $R$, Mehta $A$. To assess the epidemiological risk factors and feeding practices in SAM children of Gorakhpur area. International Journal of Advanced Research 2016;4(3):231-4.

13. Bhutta ZA, Ahmed T, Black RE, et al. What works? Interventions for maternal and child under nutrition and survival. The Lancet 2008;371(9610):417-40.

14. Heaver R, Kachondam. Thailand's National nutrition program: lessons in management and capacity development. The World Bank, Washington DC, USA: 2002. 